\title{
ESTIMATING THE VALUE OF A POSITIVE CHANGE IN TROUT FLY-Fishing QUaLITY IN THE RHOdes Trout Fishery, Eastern Cape, South Africa
}

\author{
M Du Preez and DE Lee
}

Department of Economics, Nelson Mandela Metropolitan University

Accepted January 2010

\begin{abstract}
The Rhodes trout fishery, located in the North Eastern Cape, is one of South Africa's premier flyfishing destinations. The integrity of the fishery is, however, under threat due to various land-use practices, which could weaken its appeal as a tourist attraction. The aim of this study is to estimate the amount recreational users are willing to pay for a project to improve the trout habitat of waters managed by the Wild Trout Association (WTA) in this fishery in order to improve its fish population density by 100 per cent. Data were collected from a biased sample of 96 respondents via a questionnaire during September 2006 to September 2007. The median estimated willingness-topay (WTP) for the project was R245 per annum per person, and the total WTP was estimated at R171 500 per annum. A valuation function to predict WTP responses was also estimated, and showed that gross annual pre-tax income and the number of visits per annum were positive determinants of WTP. The results of this study show that policy-makers should take heed of the importance trout fly fishers attach to this fishery when declaring trout zones in the upper catchments of South Africa. The aggregate WTP estimation, however, constitutes only a partial analysis of value. A number of other factors and environmental value streams need to be analysed and compared with the value estimates generated by this study if adequate holistic decision-making is to take place with regard to trout stream improvement. More specifically, the aggregate WTP estimated in this study must be viewed as only one input into a comprehensive social cost-benefit analysis to determine the desirability of trout stream improvement for wider society.
\end{abstract}

JEL Q51

\section{1}

\section{Introduction}

The Rhodes trout fishery, located in the North Eastern Cape, is one of South Africa's premier fly-fishing destinations. This fishery is important from an economic perspective since it provides a two-tier service: first, as a source of household income in one of the most rural and underdeveloped areas in South Africa, and second, as a creator of tourism-related job opportunities (Bainbridge, Alletson, Davies, Lax \& Mills, 2005). The integrity (in terms of trout habitat) of the fishery is, however, under threat due to various land-use practices, which could weaken its appeal as a tourist attraction (Steynberg, 2008). The land use practices mainly responsible for this degradation include grazing, dam and road construction and numerous other agricultural practices, such as cultivated lands adjacent to streams. Very little, if any, improvement of the rivers and streams comprising the Rhodes fishery has occurred over the last century (Steynberg, 2008).

Trout stream improvement programmes are very popular in the United States of America (see Hunter, 1991). In most cases, stream improvement entails the strategic placement of 
cover structure, such as boulders, half logs and bank covers, so as to increase the number of in situ hiding places for fish, as well as the protection of naturally occurring riparian vegetation. The latter entails fencing off the riparian corridor adjacent to the stream. Studies have shown that this type of improvement increases population densities (i.e. the number of fish per unit area - per acre in the case of the United States) by between 40 and 2300 per cent, depending on the increased percentage cover provided (see Quinn, 1994; Hunt, 1988; Hunt, 1992). More specifically, a seminal study of stream improvement involving cover enhancement in Montana, United States of America, showed that the abundance of trout increased by more than 300 per cent following the addition of cover to approximately 5 per cent of the stream area (Boussu, 1954).

Although it may appear that trout stream improvement, as described above, is solely focused on the manipulation of the stream in favour of trout, the overall goal is to allow the stream to heal itself (Hunter, 1991). A healthy stream and riparian zone not only benefits trout but also improves water quality, stream bank stability (i.e. reduced erosion), and the preponderance of aquatic insects and instream vegetation (Hunter, 1991; Quinn, 1994). Indigenous fish species, such as yellowfish, which coexist with alien trout in some of the waters of the Rhodes fishery for parts of a year, may very well also benefit from improved stream and riparian area conditions as many of their requirements for survival and reproduction are not too dissimilar from those of trout (Steynberg, 2008). A study by Quinn (1994) showed that trout stream improvement projects had a positive effect on the size of populations of other fish species communities.

Over and above fish abundance, fishing success $^{1}$ also, however, depends on many other exogenous factors, such as the level of angler skill, the type of fishing that takes place and the time when fishing takes place. This paper, however, does not incorporate these factors, but rather suggests that an increase of in situ cover and streamside vegetation due to stream improvement leads to a higher carrying capacity, which increases the density of trout stock, which makes it easier for fly fishers to catch fish. ${ }^{2}$ The authors acknowledge that fly fishers with dissimilar skill levels will undoubtedly catch dissimilar numbers of trout.

The value of catching more fish, especially trout, is important from a resource policy point of view. Recent government legislation (i.e. the National Environmental Management: Biodiversity Act, No. 10 of 2004), which calls for the complete eradication of trout from certain South African catchments (National Environmental Management Amendment Act, 2004), could have a detrimental effect on the people who are dependent on these trout for their livelihoods. Monetary estimates of peoples' preferences for catching more trout can assist in fishery management decisions, such as awarding zoning rights for trout fisheries in upper catchments. According to the Act, trout in South Africa will be managed by means of a zoning system. ${ }^{3}$ Within the declared zones, trout fishing and farming will be promoted but outside the zones, trout fishing and farming will be strictly controlled, which includes eradication. These estimates can also be of use in comprehending the benefits associated with water quality improvement projects (McConnell \& Strand, 1994). There is a lack of South African studies that have attempted to estimate a value of peoples' preferences for improved trout fishing quality. ${ }^{4}$ This study endeavours to partly fill this gap. More specifically, the objective of this study is to estimate respondents' willingnessto-pay (WTP) for a project that would improve the trout habitat of parts of the Rhodes fishery in order to improve its fish population density by 100 per cent. ${ }^{5}$ The improvement project would entail adding cover, by means of the strategic positioning of boulders, half logs and bank covers, to approximately five per cent of the stream area, as well as the protection of the riparian corridor by means of fencing.

It should, however, be borne in mind that this study constitutes a fractional analysis of value which should be applied in wider decisionmaking. Accordingly, it is important to analyse the private and social costs of trout stream improvement and compare these in a social cost-benefit framework with the value estimates generated in this study. 
The rest of the paper is organised as follows. Section 2 describes the study area. Section 3 presents a description of the research methodology applied and the data collection process. In Section 4 the collected data are analysed and results presented. Section 5 provides conclusions and recommendations.

\section{2}

\section{The study area}

Rhodes is situated in the North-Eastern Cape and falls under the Ukhahlamba district (see Figure 1 below).

Figure 1:

Geographical location of Rhodes

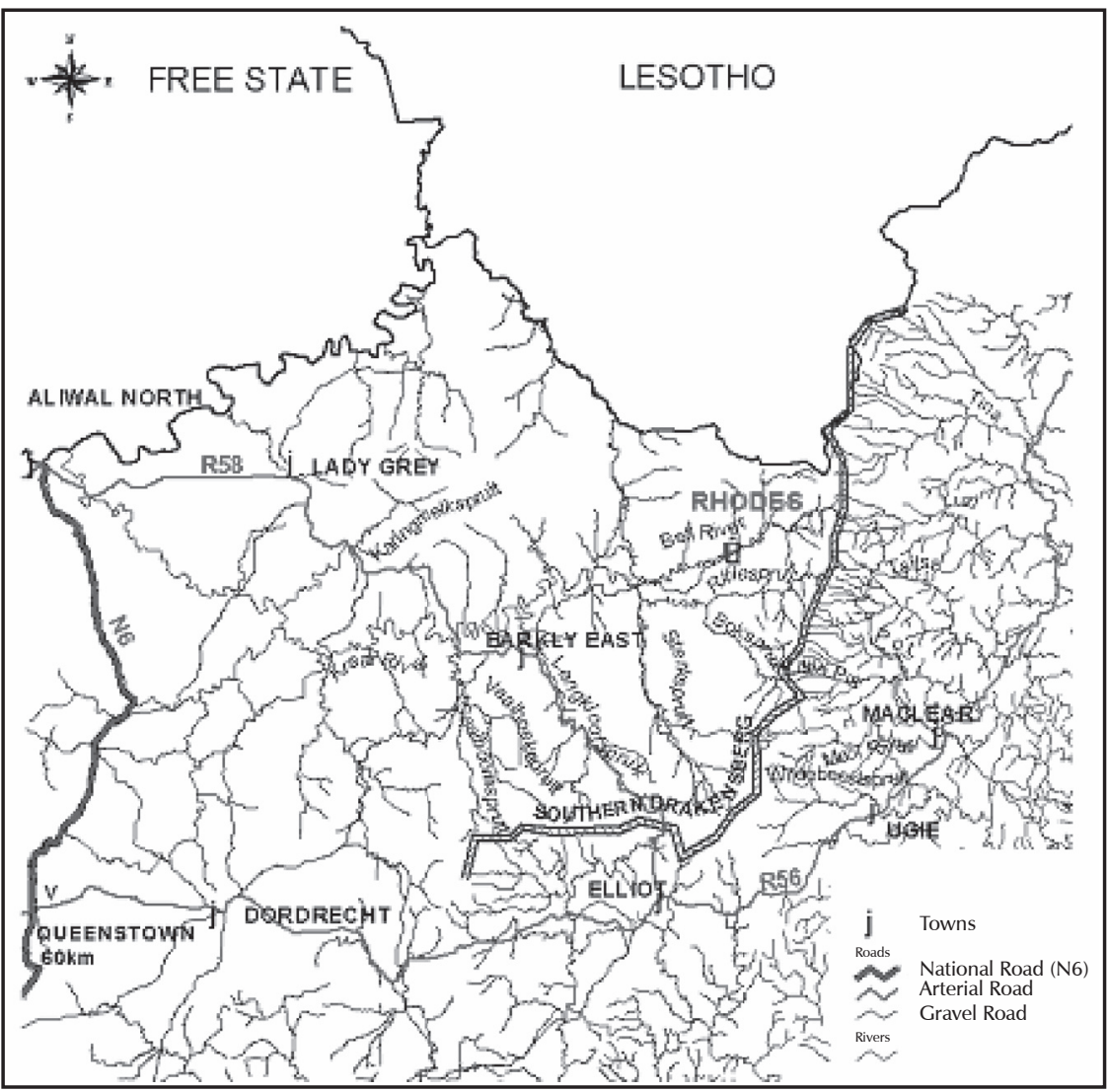

Source: Wild Trout Association (2008)

Wool and meat farming and tourism-related businesses are the main commercial activities in Rhodes (Senqu Tourism, 2008). The primary catalyst behind the development of Rhodes is its attractiveness as a tourist destination. Tourists visit Rhodes to enjoy recreational activities such as fly-fishing, hunting, horseback riding, mountain biking, bird watching, hiking and snow skiing. The rivers and streams that comprise the Rhodes fishery are easily accessible and mainly inhabited by a self-sustaining population of wild trout (both Rainbow and Brown) and for these reasons Rhodes village has become one of South Africa's premier trout fly-fishing destinations. The average trout biomass per kilometer of stream is currently estimated to be approximately 15 pounds $^{6}$ (6.8 kilograms) (Steynberg, 2008). The trout fishing season in the Rhodes region runs from September to March of every year. Indigenous yellowfish are absent from the higher reaches of most of the streams of the Rhodes fishery. These fish 
migrate up to the lower to middle reaches of these streams only during their spawning season in summer.

Local fly-fishing guides, the Mosheshs's Ford Angling Club and the Wild Trout Association (WTA) are tasked with the management of the Rhodes trout fishery on behalf of riparian landowners. This study focuses solely on estimating the value of peoples' preferences for improving the quality of trout fishing in the streams managed by the WTA. The WTA manages sections of the Kraai, Bell, Bokspruit, Sterkspruit, Riflespruit, Langkloof and Joggemspruit Rivers (see Figure 1 above). Most of the streams start 2800 to 3300 metres above sea level as unspoiled, freestone streams (Steynberg, 2008).

\section{3}

\section{Research methodology and data}

The hypothesis for this study is that the people who use the environmental service flows provided by the Rhodes trout fishery are willing to pay to enhance the quality of their fishing experience. Recreational fishing trips to Rhodes are 'manufactured' by households through their time allocations and the purchasing of services provided by markets. These actions in turn are integrated with natural resource use (in this case the trout fishery). The natural resource to a large extent exhibits a public good nature. Accordingly, one user's consumption of the fishery's services does not necessarily diminish other users' consumption levels, and if the streams and rivers are not heavily congested with users, then it is less likely to diminish the utility other users derive from consuming their services. In this case, a questionnaire survey can be used to obtain data on the preferences and characteristics of trout fishery users. The survey allows for the direct elicitation of monetary estimates by asking respondents to state the money amount they would be willing to pay to secure an improvement of the environmental service flow in question - this type of study is known as a contingent valuation (CV) (Perman, Ma \& McGilvray, 1996).

Guidelines for performing CV studies are laid out in the Report to the NOAA Panel on
Contingent Valuation (see Arrow et al., 1993). Briefly, the NOAA Report guidelines are as follows:

- The researcher must explain the sampling design process;

- The researcher should attempt to minimise non-responses;

- The researcher should use face-to-face interviews instead of mail or telephone surveys;

- The researcher should conduct a pilot survey to test the survey instrument;

- The researcher should use the willingnessto-pay (WTP) format instead of the willingness-to-accept (WTA) format;

- The valuation question should be the referendum type format;

- The project, environmental good or service being valued should be adequately described;

- Respondents must be reminded of substitutes for the good or service being valued;

- The valuation question must correspond to a future event and not one that has already taken place;

- A follow-up question to the valuation question, which asks the respondent why he/she stated the amount he/she stated, should be included;

- The researcher should ask a variety of different questions that assist in interpreting the WTP values elicited; and

- The researcher should make the respondents aware that they face a budget constraint (Arrow et al., 1993).

The first step taken in the CV was to determine the target population and sampling frame and select a representative sample from the latter. A problem encountered in this regard was whom to include as non-users in the target population and the sample frame. Non-users, along with users, derive non-use or passive use values from the intangible use of the environment, such as the satisfaction derived from preserving an environmental good (Pearce \& Turner, 1990). Non-use values can be split up into existence, option and bequest values. Existence value is 
defined as the satisfaction derived by individuals from the preservation of an environmental good although these people might never enjoy consuming it (Pearce and Turner, 1990). Option value refers to the premium people are willing to pay to retain future use of an environmental good (Hanley \& Spash, 1993). Bequest value is defined as the willingness-to-pay to preserve an environmental good for the potential use and benefit of future generations (Pearce \& Turner, 1990).

The problem of which non-users to include could, however, not be satisfactorily resolved in this study. The target population and thus the sample frame estimates are biased in the sense that they understate individual and aggregate WTP as the non-use values of both visitors and non-visitors were not captured in this study.? The target population originally comprised all the users of the Rhodes trout fishery, while the sampling frame was defined as fly-fishers who purchase day permits from the WTA in order to gain access to the fishery's waters. By averaging total annual visits to WTA streams from 2002 to 2006, based on individual day permit sales, it was estimated that, on average, 700 fly-fishers visit the Rhodes fishery per year.

With a population size of 700 individuals and a desired level of precision equal to 10 per cent, the minimum required sample size was estimated to be $88^{8}$ (Bartlett et al., 2001). The pre-coded questionnaire, used as the survey instrument in this study, was pre-tested during a pilot survey. After the pilot study, the questionnaire was simplified and improved (see Appendix A). A total of 96 respondents were eventually interviewed face-to-face during the period September 2006 to September 2007. Non-responses were zero.

An attempt was made to convey reliable and realistic information to respondents concerning the contingent trout fishing market in question. The CV was carried out to estimate the WTP per annum, by fly-fishers visiting the Rhodes fishery, for a project that will ensure the improvement of the rivers and streams, in order to improve their trout population density by 100 per cent. The improvement project would entail adding cover, by means of the strategic positioning of boulders, half logs and bank covers, to approximately
5 per cent of the stream area, as well as the protection of the riparian corridor by means of fencing. The project will increase the likelihood that the average trout biomass per kilometer of stream increases to 30 pounds (13.64 kilograms) - this represents a doubling of the biomass compared to the status quo. The WTP question corresponded to a potential future event and not one that had already occurred.

Respondents were made aware of substitute sites available for the Rhodes trout fishery in the trout stream improvement project. These substitute sites included fisheries in the Cape, Free State, Mpumulanga, KwaZulu-Natal, Gauteng, Botswana and Zimbabwe.

The questionnaire also contained an explanation of the payment mechanism (i.e. bid vehicle). The choice of the bid vehicle is important since it can influence the mean bid. If entry fees are charged to visit an environmental resource, some respondents may feel this would debase their recreation experience and make protest bids (Mitchell \& Carson, 1989). Protest bids might also be encountered if the bid vehicle used is a tax since respondents are often hostile towards taxes (Hanley, Shogren \& White, 1997). The administered questionnaire stated that respondents would be required to pay an annual fly-fishing levy - this bid vehicle was seen as both realistic and uncontroversial to respondents. Money raised through the annual fly-fishing levies was to be used to finance the project valued. The funds would be collected and administered by the WTA. Respondents were reminded that this amount would be over and above what they already pay to access the fly-fishing services of the Rhodes fishery.

The respondents were also reminded that spending more money on the project would mean that they would have less money to spend on all other goods and services, i.e. they faced a budget constraint. This reminder was given in an attempt to reduce mental account bias. This bias relates to the fact that the sum of the respondents' income, wealth and time is a fixed total which is apportioned across all environmental goods and services (Hanley \& Spash, 1993). One can denote the gross environmental budget $\mathrm{B}$, and the amounts apportioned to any good or service $i, B_{i}$. Mental 
account bias occurs if a CVM estimate of mean value for $i$ is sought, and a respondent bids an amount $\hat{B}_{i}$; where $\hat{B}_{i}>B_{i}$.

Since the objective of this study was to value use rather than non-use value, rigorous observance of all the recommendations of the NOAA Report is neither necessary nor appropriate. This study thus adopted a payment card approach to elicit each respondent's WTP amount, rather than the referendum type format recommended in the NOAA Report for non-use values. The reasons for choosing this elicitation method are that respondents were familiar with the consumption of the good and the costs of fly-fishing for other types of fish. The use of the payment card method prevents starting point bias $^{9}$ since the respondent is presented with a visual aid containing a large set of ordered monetary amounts. Respondents were asked to circle the amount that represented their maximum willingness-to-pay for the project in question. The listed set of monetary amounts was chosen in accordance with the typical expenditure by respondents on other publicly provided services such as those suggested by Hanley and Spash (1993).

The questionnaire was also prepared to obtain information on: equipment costs incurred per visit; access costs incurred per visit; trout catch rates per visit; the frequency of visits; distances travelled to visit substitute sites; and personal information about the respondent, including age, race, level of education, level of income and gender.
4

\section{Empirical analysis and results}

\subsection{Estimation of the bid curve}

A Tobit model was estimated using the survey data in order to generate a predictive model of individual annual WTP. The Tobit model was preferred since the dependent variable is censored at zero - the use of the ordinary least squares (OLS) model in this case would lead to biased estimators. The parameters of the Tobit model are estimated using the Maximum Likelihood procedure. It involves estimating the parameters in such a manner that the probability of observing the given dependent variable is as high as possible (Gujarati, 2003).

The predictive model for the $\mathrm{m}^{\text {th }}$ individual took the following form:

$Y_{m}=\sum_{i=1}^{n} \beta_{i} X_{m i}+\varepsilon$

where $Y_{m}=$ the individual annual WTP (Rand), $X_{i}=$ a vector of $\mathrm{n}$ explanatory variables, $\beta_{i}$ is a vector of $n$ parameters to be estimated, and $\varepsilon$ is the disturbance term.

The independent (explanatory) variables included in the model and the a priori expectations for the sign of their influence on WTP are shown in Table 1 below. The selection of the independent variables was based on the recommendations of the NOAA Report (Arrow et al., 1993) and CVM manuals (see for example Mitchell and Carson, 1989; Hanley and Spash, 1993).

Table 1:

Tobit model independent variables

\begin{tabular}{|l|l|c|}
\hline \multicolumn{1}{|c|}{ Independent variables } & \multicolumn{1}{|c|}{ Operational definitions } & $\begin{array}{c}\text { Expected sign } \\
\text { of coefficient } \\
\text { estimates }\end{array}$ \\
\hline Access costs/trip & $\begin{array}{l}\text { Cost of accessing the site per trip (a continuous variable } \\
\text { expressed in Rands) }\end{array}$ & - \\
\hline Equipment costs/trip & $\begin{array}{l}\text { Cost of equipment purchases per trip (a continuous variable } \\
\text { expressed in Rands) }\end{array}$ & - \\
\hline Favourite substitute site & $\begin{array}{l}\text { Roundtrip distance costs to most desired substitute site } \\
\text { expressed in Rands (a continuous variable) }\end{array}$ & + \\
\hline Catch rate/trip & Number of fish caught per trip (a continuous variable) & + \\
\hline
\end{tabular}




\begin{tabular}{|l|l|c|}
\hline Visits/annum & Number of visits per annum (a continuous variable) & + \\
\hline Income & $\begin{array}{l}\text { Gross pre-tax income per annum (a continuous variable } \\
\text { expressed in Rands) }\end{array}$ & + \\
\hline Gender & $\begin{array}{l}\text { A dummy variable coded } 1 \text { if the respondent is male; 0 if a } \\
\text { female }\end{array}$ & + \\
\hline Age & A continuous variable expressed in years & + \\
\hline Education & $\begin{array}{l}\text { Number of years of schooling completed (a continuous } \\
\text { variable) }\end{array}$ & + \\
\hline Race & $\begin{array}{l}\text { A dummy variable coded } 1 \text { if the respondent is white; } 0 \text { if } \\
\text { non-white }\end{array}$ & $?$ \\
\hline
\end{tabular}

Reasons for the hypothesised predicted signs of the coefficient estimates are described below.

\section{Access costs/trip:}

It was expected that respondents who incur higher access costs per trip would be willing to pay less for a project aimed at improving parts of the trout waters managed by the WTA. Spending more money to access the fishery implies that the individual has less money available to spend on other things (i.e. he/she faces a budget constraint).

\section{Equipments costs/trip:}

It was expected that respondents who spend more on equipment per trip would be willing to pay less for a project aimed at improving parts of the trout waters managed by the WTA. Spending more on equipment implies that the individual has less money available to spend on other things (i.e. he/she faces a budget constraint).

\section{Favourite substitute site:}

Respondents who incur higher travel costs to visit their most favoured substitute fishing site were expected to be willing to pay more for a project aimed at improving parts of the trout waters managed by the WTA. Stated differently, if an individual lives in close proximity to a substitute recreational fishery, it can be expected that he/she would be willing to pay less for a trout stream improvement project.

\section{Catch rate/trip:}

Respondents who catch more fish per fishing trip were expected to be more willing to pay for a project aimed at improving parts of the trout waters managed by the WTA. Improved catch rates per annum translates into the achievement of a higher level of utility.

\section{Visits/annum:}

It was expected that more frequent visitors to the Rhodes fishery would willing to pay more for a project aimed at improving parts of the trout waters managed by the WTA.

\section{Income:}

Respondents with higher annual incomes were expected to be willing to contribute more for a project aimed at improving parts of the trout waters managed by the WTA than low-income earners, simply because they have higher levels of disposable income.

Gender:

Female fly-fishers were expected to be willing to pay less for a project aimed at improving parts of the trout waters managed by the WTA than male fly-fishers, since they potentially face a more restrictive budget constraint.

Age:

Older respondents were expected to possess more disposable income than younger respondents and were thus expected to be more inclined to pay for a project aimed at improving parts of the trout waters managed by the WTA.

\section{Education:}

Respondents who had attained higher education levels were expected to have a broader understanding of the issue at hand and have higher levels of disposable income and as such it was 
expected that they would be more inclined to pay for a project aimed at improving parts of the trout waters managed by the WTA.

Race:

The researchers had no expectation as to the direction of the influence of race on individual annual WTP.
The observed ${ }^{10}$ mean, median, minimum and maximum values for the dependent and continuous independent variables used in estimating the predictive Tobit model of annual individual WTP (see Equation 1 above) are presented in Table 2 below.

Table 2:

Observed mean, median, minimum and maximum values of the dependent variable and continuous independent variables

\begin{tabular}{|l|r|r|r|r|}
\hline \multicolumn{1}{|c|}{ Variable } & Mean & Median & Min & Max \\
\hline Individual WTP/annum (Rands) & 270.49 & 250.50 & 0 & 450.50 \\
\hline Access costs/trip (Rands) & 1562.10 & 950 & 0 & 12300 \\
\hline Equipment cost/trip (Rands) & 1087.20 & 750.00 & 0 & 7500.50 \\
\hline Annual gross income before tax (Rands) & 848020 & 875000 & 60000 & 1500000 \\
\hline Favourite substitute sites (Rands) & 6938.79 & 6057 & 400 & 19538 \\
\hline $\begin{array}{l}\text { Catch rate/trip (number of fish caught } \\
\text { per trip) }\end{array}$ & 34.67 & 17.75 & 0 & 205 \\
\hline Visits/annum & 1.6 & 1 & 1 & 69 \\
\hline Age (years) & 14.51 & 15 & 19 & 16 \\
\hline Education (years) & & & 12 & 6 \\
\hline
\end{tabular}

The observed mean annual individual WTP to improve trout habitat is $\mathrm{R} 270.49$, while the median annual individual WTP to improve trout habitat is R250.50. On average, respondents spend R1 562 and R1 087, respectively, per fishing trip on access fees and equipment. Access costs include beat permit costs and guide and instructor fees. Fly-fishing guides in the Rhodes area charge up to R1 600 per guiding day. Also included in the access costs is a fee that visiting fly fishers pay (i.e. R100 per person per day) to fish the waters managed by the WTA. Respondent ages ranged between 19 and 69 years, with a mean and median age of 41 years. The average respondent earns a gross annual pre-tax income of R848 020 with a minimum income of R60 000 and a maximum income of R1 500 000. Table 2 above also shows the following: fly fishers on average visit the Rhodes fishery 1.6 times per annum and catch on average 35 trout per trip. The average round trip distance cost of respondents visiting their favourite substitute fly-fishing destination is R6 939.

Bid curves can be estimated using a onestage or a two-stage procedure. Regardless of the process chosen, it remains very important to estimate a bid function containing all the appropriate explanatory variables for WTP (i.e. the estimation of the complete model). Subsequent to an analysis of the significance of the coefficients in the complete model, another model may be estimated in which only coefficients significant in the complete model are included. The overall explanatory power of this reduced model and the significance of the coefficients may provide more insight into the relationships being examined. A two-stage approach was adopted in this study. The results of the complete Tobit model estimated in Stata 10.1 are shown in Table 3 below. 


\section{Table 3:}

Coefficient estimates for the Tobit model of annual individual WTP for trout stream improvement, Rhodes trout fishery, 2006-2008 - a complete model

\begin{tabular}{|l|c|c|c|c|}
\hline \multicolumn{1}{|c|}{ Variables } & Coefficient & Std. error & Z-statistic & Prob. \\
\hline Access costs/trip & -0.0039786 & 0.0098307 & -0.40 & 0.687 \\
\hline Equipment costs/trip & 0.021988 & 0.0135488 & 1.62 & 0.108 \\
\hline Catch rate/trip & 0.1693286 & 0.5782303 & 0.29 & 0.770 \\
\hline Visits/annum & 48.03711 & 16.75486 & 2.87 & 0.005 \\
\hline Substitutes & -0.0059523 & 0.0034737 & -1.71 & 0.090 \\
\hline Race & 134.8294 & 127.6584 & 1.06 & 0.294 \\
\hline Income & 0.0001155 & 0.0000536 & 2.16 & 0.034 \\
\hline Gender & -122.1582 & 68.23348 & -1.79 & 0.077 \\
\hline Education & 9.399992 & 15.87786 & 0.59 & 0.555 \\
\hline Age & 1.31444 & 1.677805 & 0.78 & 0.436 \\
\hline Constant & -108.4776 & 261.0005 & -0.42 & 0.679 \\
\hline$\chi^{2}$ & 22.61 & & & \\
\hline Log likelihood & -575.92077 & & & \\
\hline $\mathrm{n}$ & 96 & & & \\
\hline
\end{tabular}

Table 3 above shows that, at the five per cent significance level, only two estimated coefficients are statistically significant in the Tobit model of annual individual WTP to improve trout habitat in the Rhodes fishery for the sample respondents. These were for visits/annum and income. Seven out of the ten explanatory variables had coefficients with the expected signs (see Table 1). The estimated coefficient signs for equipment costs/trip, favourite substitute site and gender are contrary to what was expected. Given these contrary results, tests for the presence of multicollinearity in the study data were conducted. The presence of multicollinearity may lead to implausible results and/or wrong coefficient signs (Gujarati, 2003). More specifically, a correlation matrix of the partial correlation of WTP with all independent variables (see Table 4 below), and a correlation matrix showing the correlation coefficients between all of the independent variables (see Table 5 below) were estimated.

Table 4:

Partial correlation of WTP with all independent variables

\begin{tabular}{|l|c|c|}
\hline \multicolumn{1}{|c|}{ Independent variable } & Corr. & Sig. \\
\hline Access costs/trip & -0.0539 & 0.620 \\
\hline Equipment costs/trip & 0.1679 & 0.120 \\
\hline Catch rate/trip & 0.0504 & 0.643 \\
\hline Visits/annum & 0.2888 & 0.007 \\
\hline Substitutes & -0.1768 & 0.101 \\
\hline
\end{tabular}




\begin{tabular}{|l|c|c|}
\hline Race & 0.1234 & 0.255 \\
\hline Income & 0.2257 & 0.036 \\
\hline Gender & -0.1769 & 0.101 \\
\hline Education & 0.0346 & 0.750 \\
\hline Age & 0.1079 & 0.320 \\
\hline
\end{tabular}

Table 4 above indicates the absence of multicollinearity between WTP and the independent variables selected. The analysis of the correlation matrix in Table 5 below shows the lack of obvious dependencies between the explanatory variables selected.

Table 5:

Correlation matrix for all the independent variables

\begin{tabular}{|c|c|c|c|c|c|c|c|c|c|c|}
\hline & $\begin{array}{l}\text { Access } \\
\text { costs/ } \\
\text { annum }\end{array}$ & $\begin{array}{c}\text { Equipment } \\
\text { costs/ } \\
\text { annum }\end{array}$ & $\begin{array}{c}\text { Catch } \\
\text { rate/trip }\end{array}$ & $\begin{array}{l}\text { Visits/ } \\
\text { annum }\end{array}$ & $\begin{array}{l}\text { Sub- } \\
\text { stitute }\end{array}$ & Race & Income & Gender & $\begin{array}{l}\text { Edu- } \\
\text { cation }\end{array}$ & Age \\
\hline $\begin{array}{l}\text { Access costs/ } \\
\text { annum }\end{array}$ & 1.000 & & & & & & & & & \\
\hline $\begin{array}{l}\text { Equipment } \\
\text { costs/annum }\end{array}$ & 0.103 & 1.000 & & & & & & & & \\
\hline Catch rate/trip & 0.020 & 0.024 & 1.000 & & & & & & & \\
\hline Visits/annum & 0.233 & -0.077 & -0.129 & 1.000 & & & & & & \\
\hline Substitute & 0.069 & 0.048 & -0.023 & 0.151 & 1.000 & & & & & \\
\hline Race & -0.01 & -0.004 & -0.003 & -0.108 & -0.051 & 1.000 & & & & \\
\hline Income & 0.166 & 0.222 & 0.006 & 0.081 & 0.076 & 0.012 & 1.000 & & & \\
\hline Gender & -0.15 & 0.042 & 0.014 & 0.096 & -0.124 & 0.219 & 0.090 & 1.000 & & \\
\hline Education & 0.148 & 0.001 & -0.057 & -0.120 & -0.061 & 0.113 & 0.422 & 0.060 & 1.000 & \\
\hline Age & 0.183 & -0.105 & 0.078 & -0.046 & 0.088 & -0.022 & 0.315 & -0.033 & 0.102 & 1.000 \\
\hline
\end{tabular}

Based on the results shown in Tables 4 and 5 above, it may thus be concluded that no serious correlation problem encumbers the bid function estimated.

The second stage of the bid function estimation procedure entailed the estimation of a reduced model. Accordingly, the coefficients which were statistically significant (at the five per cent level) in the complete model (see Table 3 above) were used to estimate a reduced Tobit model. The results of the reduced Tobit model estimated in Stata 10.1 are shown in Table 6 below. 


\section{Table 6:}

Coefficient estimates for the Tobit model of annual individual WTP for trout stream improvement, Rhodes trout fishery, 2006-2008 - a reduced model

\begin{tabular}{|l|c|c|c|c|}
\hline \multicolumn{1}{|c|}{ Variables } & Coefficient & Std. error & z-statistic & Prob. \\
\hline Visits/annum & 32.79309 & 15.67859 & 2.09 & 0.039 \\
\hline Income & 0.0001449 & 0.0000454 & 3.19 & 0.002 \\
\hline Constant & 85.29605 & 48.4204 & 1.76 & 0.081 \\
\hline$\chi^{2}$ & 14.61 & & \\
\hline Log likelihood & -579.92065 & & \\
\hline $\mathbf{n}$ & 96 &
\end{tabular}

Table 6 above shows that the coefficient of the income variable is statistically significant at the 1 per cent level. The positive sign denotes that the higher the respondent's gross annual pre-tax income the more he/she is willing to pay. This result accords with a priori expectations. The table also shows that respondents who visit the Rhodes fishery more frequently were willing to pay more for the trout habitat improvement project. This result also accords with what was expected. The coefficient of the visits/annum variable is statistically significant at the 5 per cent level.

The complete and reduced Tobit models were compared by using the log-likelihood ratio test. This test is based on the difference in the log-likelihood functions for the complete and reduced models.

The log-likelihood ratio test statistic is given as:

$$
\text { Likelihood ratio }=-2\left(L_{R}-L_{C}\right)
$$

where $L_{R}=$ the $\log$-likelihood value of the reduced model, and $L_{C}=$ the log-likelihood value of the complete model.

The rejection region at the five per cent level of significance is given as:

Likelihood ratio $\geq \chi_{0.05}^{2}(v)$
The complete Tobit model and the reduced Tobit model yielded log-likelihood values of -575.92077 and -579.92065 , respectively. The log-likelihood ratio statistic value was calculated to be 7.99976 , while the chi-square $\left(\chi^{2}\right)$ critical value, corresponding to the upper five per cent significance level with eight degrees of freedom, was 15.5073 . The log-likelihood ratio test statistic does not exceed the chi-square critical value. The reduced Tobit model is thus preferred, as the null hypothesis cannot be rejected. There is sufficient evidence to infer that none of the independent variables omitted from the reduced Tobit model contributes significant information for the prediction of WTP.

\subsection{Aggregation of the data}

Using the regression results from the reduced Tobit model in Table 6 above, the mean and median annual individual WTP for a project that will improve the trout habitat of the waters of the Rhodes fishery managed by the WTA are estimated in this section. The observed mean and median values for the selected explanatory variables, provided in Table 2 above, were used to predict the mean and median annual individual WTP, respectively. Table 7 below summarises these results.

where $v=$ the number of parameters tested. 


\section{Table 7}

Mean and median annual individual WTP for the improvement of the trout habitat of the WTA-managed waters of the Rhodes fishery

\begin{tabular}{|l|l|}
\hline \multicolumn{1}{|c|}{ WTP measure } & \multicolumn{1}{c|}{ Amount (R) } \\
\hline Mean annual individual WTP & 261 \\
\hline Median annual individual WTP & 245 \\
\hline
\end{tabular}

The mean annual individual WTP is R16 higher than the median annual individual WTP. The total WTP per annum for a trout stream improvement project in the waters managed by the WTA was estimated using the median annual individual WTP value instead of the mean annual individual WTP value as it provides a more accurate and conservative estimate (Hanley \& Spash, 1993). Given the target population of 700 trout fly-fishers, the total WTP for improving the trout waters managed by the WTA in the Rhodes fishery is R171 500 per annum.

The estimation of the aggregate WTP for trout stream improvement, however, constitutes a partial analysis of value which should be applied in broader decision-making. The latter requires that a comprehensive social cost-benefit analysis be conducted in which the private and social costs of trout stream improvement be identified and valued, where possible, and compared with the value estimates generated in this study. Thus, caution should be applied to viewing the results of this study as an unqualified endorsement of trout habitat improvement.

\section{5}

\section{Conclusion}

The integrity (in terms of trout habitat) of the Rhodes trout fishery, which is a source of income and tourism-related jobs, is under threat due to various land-use practices. The objective of this study was to estimate the willingness-to-pay for a project that would improve the trout habitat of the Rhodes fishery in order to improve its fish population density by 100 per cent, based on a survey of respondents that use trout waters managed by the Wild Trout Association. The improvement project would entail adding cover, by means of the strategic positioning of boulders, half logs and bank covers, to approximately 5 per cent of the stream area, as well as the protection of the riparian corridor by means of fencing. The project will increase the likelihood that the average trout biomass per kilometer of stream increases to 30 pounds (13.64 kilograms) - this represents a doubling of the biomass compared to the status quo. An increase of in situ cover and streambank vegetation due to stream improvement would lead to a higher carrying capacity, thereby increasing the density of trout stock, making it easier for fly fishers to catch fish, and thus enhancing the quality of the recreational trip.

Estimates of the value of catching more fish, especially trout, are important from a resource policy point of view. Recent government legislation (i.e. the National Environmental Management: Biodiversity Act, No. 10 of 2004), which calls for the complete eradication of trout from certain South African catchments, could have a detrimental effect on the people who are dependent on these trout for their livelihoods. Monetary estimates that reflect peoples' preferences for catching more trout can assist in fishery management decisions, such as awarding zoning rights for trout fisheries in upper catchments. These estimates can also be of use in comprehending the benefits associated with water quality improvement projects (McConnell \& Strand, 1994).

The sample respondents were each willing to pay R245 per annum for the project in question. Given the target population of 700 fly-fishers, the aggregate willingness-to-pay for improving the trout waters managed by the Wild Trout Association (WTA) in the Rhodes fishery is R171 500 per annum. A Tobit model valuation function to predict willingness-to-pay responses was also estimated, and showed that gross annual pre-tax income and the number of 
visits per annum were positive determinants of willingness-to-pay.

This conclusion is subject to two important qualifications. First, non-use values for both users and non-users of the waters managed by the WTA were not captured in this study due to the difficulties encountered in identifying all affected users and non-users. This analysis could, therefore, be criticised as reporting individual and aggregate willingness-to-pay estimates that are considerably understated. Second, it should be borne in mind that this study constitutes a partial analysis of value which should, ideally, be applied in wider decision-making. To this end, the private and social costs of trout stream improvement must, ideally, be analysed and compared in a social cost-benefit setting with the value estimates generated in this study. Thus, caution should be applied to viewing the results of this study as providing categorical support for trout habitat improvement.

\section{Acknowledgements}

The authors gratefully acknowledge the useful comments made by two anonymous referees. The authors would also like to thank Mr P. Gatogang for his assistance with data capturing.

\section{Endnote}

1 Fishing success and the quality associated with a recreational fishing trip are viewed as synonymous in this paper.

2 A similar argument can be found in McConnell and Strand (1994).

3 At the time of writing these zones had not been declared.

4 The most popular way to measure the quality fishermen attach to a fishing trip is in terms of abundance (see Vaughan and Russell, 1982). Abundance is measured in terms of number of fish or biomass per unit area.

5 This is a very conservative estimate (see studies by Hunt, 1988; Hunt, 1992; Quinn, 1994).

6 This figure was not scientifically determined, but is based on an estimate made by a professional fly-fishing guide who has guided clients in this area for the last 20 years. In excess of 120 guiding days per annum are spent by the guide on the rivers and streams that comprise the fishery.
7 An anonymous referee argued that trout flyfishers would also likely have option, existence and bequest values, not only non-visitors to the Rhodes trout fishery.

$8 \mathrm{n}=\mathrm{N} / 1+\mathrm{N}$. $(\mathrm{e})^{2}$ where $\mathrm{n}=$ the sample size, $\mathrm{N}=$ the population size, and $\mathrm{e}=$ the level of precision.

9 Starting point bias refers to the tendency of respondents to make WTP estimates based on some initial value embedded in the survey instrument (Hanley and Spash, 1993).

10 Observed" in this case refers to the values captured on the survey instrument.

\section{References}

ARROW, K., SOLOW, R., PORTNEY, P., LEARNER, E., RADNER, R. \& SCHUMAN, H. 1993. Report to the NOAA panel on contingent valuation. Washington: Federal Register.

BAINBRIDGE, W., ALLETSON, D., DAVIES, M., LAX, I. \& MILLS, J. 2005. The policy of FOSAF on the presence of trout in the freshwater aquatic systems of South Africa and Southern Africa. Johannesburg: Federation of Southern African Fly-fishers, Unpublished Report, FOSAF Secretariat.

BARTLETT, J., KOTRLIK, J. \& HIGGINS, C. 2001. Organizational research: determining appropriate sample size in survey research. Information Technology: Learning and Performance. 19(2): 43-50.

BOUSSU, M.F. (1954). Relationship between trout populations and cover on a small stream. Journal of Wildlife Management. 18(2): 229-239.

GUJARATI, D.N. 2003. Basic econometrics. ( th $^{\text {th }}$ ed.) New York: McGraw-Hill.

HANLEY, N. \& SPASH, C. 1993. Cost-benefit analysis and the environment. Vermont: Edward Elgar Publishing.

HANLEY, N., SHOGREN, J.F. \& WHITE, B. 1997. Environmental economics in theory and practice.

Basingstoke: Macmillan.

HUNT, R.L. 1988. A compendium of 45 trout stream habitat development evaluations in Wisconsin during 1953-1985. Wisconsin Department of Natural Resources Technical Bulletin. 162: 80pp.

HUNT, R.L. 1992. Evaluation of trout habitat improvement structures in three high-gradient streams in Wisconsin. Wisconsin Department of Natural Resources Technical Bulletin. 179: 40pp.

HUNTER, C.J. 1991. Better trout habitat: a guide to stream restoration and management. Washington: Island Press. MCCONNELL, K.E. \& STRAND, I.E. 1994. The economic value of mid and south atlantic sportfishing. (vol. 2) College Park: University of Maryland. 
MITCHELL, R. \& CARSON, R. 1989. Using surveys to value public goods: the contingent valuation method. Washington: Resources of the Future.

NATIONAL ENVIRONMENTAL MANAGEMENT AMENDMENT ACT 2004. (NATIONAL ENVIRONMENTAL MANAGEMENT:

BIODIVERSITY ACT, No. 10 of 2004). Cape Town: Government Printing Works.

PEARCE, D. \& TURNER, K. 1990. Economics of natural resources and the environment. New York: Harvester Wheatsheaf.

PERMAN, R., MA, Y. \& MCGILVRAY, J. 1996. Natural resource and environmental economics. New York: Longman.
QUINN, J.W. 1994. Effects of trout stream habitat rehabilitation projects on Nongame fish communities in five southeastern Minnesota streams. Conservation Biology Research Grants Program. Minnesota: Minnesota Department of Natural Resources. SENQU TOURISM, 2008. Senqu Tourism. Available: http://www.senqutourism.co.za/senqu.htm (Accessed: 2 August 2008).

STEYNBERG, F. 2008. Personal communication. Professional Fly-fishing Guide. Rhodes: Rhodes Tourism Association.

VAUGHAN, W.J. \& RUSSELL, C.S. 1982. Valuing a fishing day: an application of a systematic varying parameter model. Land Economics. 58: 450-463.

Wild Trout Association. 2008. Wild Trout Association. http://www.wildtrout.co.za. (Accessed 2 August 2008). 


\section{Appendix A}

Contingent valuation questionnaire on the improvement of the trout streams and rivers managed by the Wild Trout Association (WTA).

September 2006 - September 2007

Instructions: Please tick the appropriate blocks. If the answer is other, please provide the correct answer in the space provided alongside 'other'.

1 GENDER OF RESPONDENT:

\begin{tabular}{|c|c|}
\hline Male & Female \\
1 & 2 \\
\hline
\end{tabular}

2 RACE OF RESPONDENT:

\begin{tabular}{|l|c|}
\hline Race & \\
\hline 2.1 Black & 1 \\
\hline 2.2 White & 2 \\
\hline 2.3 Coloured & 3 \\
\hline 2.4 Indian & 4 \\
\hline 2.5 Other & 5 \\
\hline
\end{tabular}

3 HOW MANY TIMES, IN THE PAST YEAR, HAVE YOU VISITED RHODES TO FLY FISH FOR TROUT (number of trips)?

\begin{tabular}{|l|c|}
\hline No. of times & \\
\hline 1 & 1 \\
\hline 2 & 2 \\
\hline 3 & 3 \\
\hline 4 & 4 \\
\hline 5 & 5 \\
\hline 6 or more & 6 \\
\hline
\end{tabular}


4 HOW MANY ALIEN FISH (RAINBOW AND BROWN TROUT) DID YOU CATCH ON EACH SEPARATE TRIP IN MOVING WATER (NON-CLOSED SYSTEM) DURING THE LAST YEAR?

\begin{tabular}{|c|c|}
\hline Trip no. & No. of fish \\
\hline & \\
\hline & \\
\hline & \\
\hline & \\
\hline & \\
\hline & \\
\hline & \\
\hline
\end{tabular}

5 RANK YOUR FAVOURITE FLY-FISHING DESTINATIONS IN SOUTHERN AFRICA IN TERMS OF THE IMPORTANCE YOU ATTACH TO EACH:

\begin{tabular}{|c|c|c|c|c|c|}
\hline Fly fishing destination & 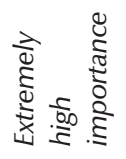 & 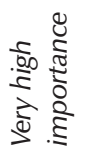 & 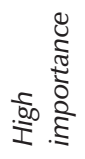 & 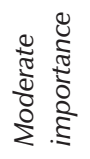 & 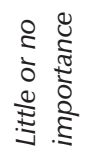 \\
\hline 5.1 North Eastern Cape (Rhodes) & 5 & 4 & 3 & 2 & 1 \\
\hline \multicolumn{6}{|l|}{ 5.2 Cape streams } \\
\hline \multicolumn{6}{|l|}{ 5.3 Freestate streams } \\
\hline \multicolumn{6}{|l|}{ 5.4 Mpumulanga streams } \\
\hline \multicolumn{6}{|l|}{5.5 KwaZulu-Natal midlands } \\
\hline \multicolumn{6}{|l|}{ 5.6 Gauteng rivers } \\
\hline \multicolumn{6}{|l|}{ 5.7 Okavango Delta (Botswana) } \\
\hline \multicolumn{6}{|l|}{ 5.8 Troutbeck Sun (Zimbabwe) } \\
\hline 5.9 Other (please specify) & & & & & \\
\hline & & & & & \\
\hline
\end{tabular}

6 WHAT IS THE ROUND TRIP DISTANCE TRAVELLED TO YOUR FAVOURITE SUBSTITUTE (FOR RHODES) FISHING DESTINATION?

\begin{tabular}{|c|c|}
\hline Site & Roundtrip Distance \\
\hline & \\
\hline
\end{tabular}

7 LOCATION OF THE VISITOR'S PERMANENT RESIDENCE:

\begin{tabular}{|l|l|}
\hline City/town & \\
\hline Province/state & \\
\hline Country & \\
\hline
\end{tabular}


8 PLEASE INDICATE THE MAKE, THE MODEL, AND THE YEAR OF THE MODEL OF THE CAR/TRUCK/SUV, AND THE AVERAGE AMOUNT OF KILOMETERS TRAVELLED PER YEAR IN THE VEHICLE SPECIFIED TO GET TO THE RHODES AREA AND BACK HOME:

\begin{tabular}{|c|c|c|}
\hline Make/model of vehicle & Year & Average kilometers travelled per year \\
\hline & & \\
\hline
\end{tabular}

9 WHAT IS THE TOTAL ACCESS COST ASSOCIATED WITH FLY-FISHING FOR TROUT DURING AN ENTIRE FISHING TRIP TO RHODES?

\begin{tabular}{|l|l|}
\hline Access cost & Cost (R) \\
\hline 9.1 Use of a guide. & \\
\hline 9.2 Use of an instructor. & \\
\hline 9.3 Beat permits (R100/Beat). & \\
\hline 9.4 Other (please specify) & \\
\hline
\end{tabular}

10 HOW MUCH MONEY ON AVERAGE DO YOU SPEND ON FLY-FISHING EQUIPMENT IN PREPARATION FOR A TRIP TO RHODES TO FLY FISH FOR TROUT?

$\mathbf{R}$

\begin{tabular}{|rrr|r|}
\hline & & 0 & 1 \\
\hline 1 & -50 & 2 \\
\hline 51 & -100 & 3 \\
\hline $101-200$ & 4 \\
\hline $201-500$ & 5 \\
\hline $501-1000$ & 6 \\
\hline $1001-2000$ & 7 \\
\hline $2001-5000$ & 8 \\
\hline $5001+$ & 9 \\
\hline
\end{tabular}

11 WHAT ARE YOU WILLING TO PAY PER ANNUM, OVER AND ABOVE WHAT YOU ALREADY PAY TO VISIT RHODES, FOR A PROJECT THAT WILL ENSURE THE IMPROVEMENT OF THE STREAMS AND RIVERS OF THE RHODES FISHERY MANAGED BY THE WILD TROUT ASSOCIATION, IN ORDER TO IMPROVE THEIR TROUT POPULATION DENSITY BY $100 \%$ ?

THE IMPROVEMENT PROJECT WOULD ENTAIL ADDING COVER, BY MEANS OF THE STRATEGIC POSITIONING OF BOULDERS, HALF LOGS AND BANK COVERS, TO ABOUT 5\% OF THE STREAM AREA AND PROTECTING THE RIPARIAN CORRIDOR BY MEANS OF FENCING. THE PROJECT WILL INCREASE THE LIKELIHOOD THAT THE AVERAGE TROUT BIOMASS PER KILOMETRE OF STREAM INCREASES TO 30 POUNDS (13.64 KGs) - THIS REPRESENTS A DOUBLING OF THE BIOMASS COMPARED TO THE STATUS QUO. 
PLEASE NOTE:

- THE PAYMENT WILL TAKE THE FORM OF A LEVY AND WILL BE COLLECTED AND ADMINISTERED BY THE WILD TROUT ASSOCIATION.

- THIS PROJECT IS AIMED AT TROUT HABITAT IMPROVEMENT OF THE RHODES FISHERY ONLY. OTHER TROUT FISHERIES ALSO EXIST IN SOUTHERN AFRICA.

- YOUR INCOME IS LIMITED AND HAS SEVERAL ALTERNATIVE USES AND THIS PROJECT IS BUT ONE OF MANY CONSERVATION PROJECTS IN SOUTH AFRICA AND THE WORLD.

\begin{tabular}{|l|c|}
\hline WTP amount (R) & \\
\hline 0 & 1 \\
\hline $1-5$ & 2 \\
\hline $6-10$ & 3 \\
\hline $11-15$ & 4 \\
\hline $16-20$ & 5 \\
\hline $21-30$ & 6 \\
\hline $31-50$ & 7 \\
\hline $51-75$ & 8 \\
\hline $76-100$ & 10 \\
\hline $101-200$ & 11 \\
\hline $201-300$ & 12 \\
\hline $301-400$ & 13 \\
\hline $401-500$ & 14 \\
\hline $500+$ & \\
\hline
\end{tabular}

12 IF YOUR ANSWER TO THE ABOVE QUESTION (QUESTION 11) IS ZERO, WHAT IS/ARE YOUR REASON/S? (YOU MAY HAVE MORE THAN ONE).

\begin{tabular}{|l|c|}
\hline Reason/s: & 1 \\
\hline 12.1 Cannot afford the fees. & 2 \\
\hline 12.2 Get no or negligible value out of rivers without trout present. & 3 \\
\hline 12.3 Abundance of service options - no scarcity, therefore why pay. & 4 \\
\hline $\begin{array}{l}\text { 12.4 Lack of confidence in Wild Trout Association to collect and use fees collected for the } \\
\text { project. }\end{array}$ & 5 \\
\hline \begin{tabular}{l} 
12.5 Other (please specify) \\
\hline
\end{tabular}
\end{tabular}


13 IF YOUR ANSWER TO THE ABOVE QUESTION (QUESTION 11) IS R500+, WHAT ARE YOUR REASONS FOR PAYING SO MUCH? (YOU MAY HAVE MORE THAN ONE).

\begin{tabular}{|l|}
\hline Reason/s: \\
\hline \\
\hline \\
\hline \\
\hline
\end{tabular}

14 AGE OF RESPONDENT:

Please specify

15 HIGHEST LEVEL OF EDUCATION OF RESPONDENT:

\begin{tabular}{|ll|c|}
\hline 15.1 & $\begin{array}{l}\text { Grade } \\
\text { (enter highest grade passed) }\end{array}$ & \\
\hline 15.2 & Post matric certificate & 2 \\
\hline 15.3 & Diploma & 3 \\
\hline 15.4 & Degree & 4 \\
\hline 15.5 & Post graduate degree & 5 \\
\hline
\end{tabular}

16 GROSS ANNUAL PRE-TAX INCOME OF RESPONDENT:

\begin{tabular}{|c|c|}
\hline \multicolumn{1}{|c|}{0} & 1 \\
\hline $1-40000$ & 2 \\
\hline $40000-120000$ & 3 \\
\hline $120001-250000$ & 4 \\
\hline $250001-500000$ & 5 \\
\hline $500001-750000$ & 6 \\
\hline $750001-1000000$ & 7 \\
\hline $1000001-1500000$ & 8 \\
\hline $1500001+$ & 9 \\
\hline
\end{tabular}

Dear respondent, we know this is a sensitive issue, but the survey is anonymous and no confidential information relating to the individual will be published. 